\title{
Pancreatico-Duodenal Artery
}

National Cancer Institute

\section{Source}

National Cancer Institute. Pancreatico-Duodenal Artery. NCI Thesaurus. Code C52992.

Either of two arteries including the inferior and superior pancreatico-duodenal arteries that supply the pancreas and duodenum. 